\title{
Perilaku Partisipasi Pemilih pada Pemilihan Kepala Daerah Kabupaten Kudus Tahun 2018
}

\author{
Mas' udi, ${ }^{1}$ Umi Qodarsasi, ${ }^{2}$ Nevy Rusmarina Dewi ${ }^{3}$ \\ ${ }^{123}$ Institut Agama Islam Negeri Kudus \\ (e-mail: ${ }^{1}$ masudijufri@stainkudus.ac.id; ${ }^{2}$ umiqodarsasi@gmail.com; \\ 3neny0708@yahoo.com)
}

\begin{abstract}
The high voter's participation in the Regional Head Election of Kudus Regency in 2018 had importance to observe. Applying qualitative approach this research try to reveal the supporting factors underlying the participative behavior in the election. It was found in the research that: Firstly, the sociological factors, such as discussion, family opinion, organizational relations, friendship interaction, working sphere, religion, and gender of the candidates; Secondly, psychological factors, which refer more to identify the candidate identities as well as the party supporters; and thirdly, rational factors, in which voters understand the vision, mission, and the program of the candidates.

Tingginya partisipasi pemilih dalam Pilkada Kabupaten Kudus tahun 2018 menarik untuk dikaji. Dengan menggunakan pendekatan penelitian kualitatif, penelitian ini mencoba untuk mengkaji faktor-faktor pendukung yang mendasari perilaku partisipatif para pemilih dalam pilkada tersebut. Ditemukan dalam penelitian itu bahwa: Pertama, adalah faktor sosiologis, seperti adanya diskusi, pendapat keluarga, lingkungan organisasi, hubungan pertemanan, lingkungan pekerjaan, agama, dan jenis kelamin calon; Kedua, faktor psikologis, yang merujuk pada identifikasi calon berdasar identitas serta partai pendukung; dan ketiga, faktor rasional, yaitu bahwa pemilih memahami visi, misi, dan program yang ditawarkan oleh calon.
\end{abstract}

Keywords: behavior; participation; political awareness; Kudus 


\section{Pendahuluan}

Pemilihan umum merupakan salah satu elemen sistem demokrasi. Salah satu tolok ukur keberhasilan penyelenggaraan pemerintahan yang demokratis adalah terlaksananya pemilu secara terbuka dan bebas, tidak ada pemaksaan dan tindakan represif dari pihakpihak yang berkepentingan. Berbeda dengan sistem politik pada masyarakat tradisional dimana elit penguasa mempunyai peran yang sangat besar dalam menentukan kebijakan politik, sehingga rakyat menjadi tersubordinasi dan cenderung kurang diperhatikan dalam kebijakan tersebut (Sastroatmojo 1995: 56). Partisipasi politik berpengaruh terhadap legitimasi masyarakat terhadap jalannya suatu pemerintahan. Dalam suatu Pemilihan Kepala Daerah (Pilkada), partisipasi politik masyarakat berpengaruh terhadap legitimasi pasangan calon gubernur dan bupati yang terpilih. Selain memberikan legitimasi, bentuk partisipasi politik lainnya dari masyarakat adalah melakukan kontrol sosial terhadap kinerja pemerintah. Pada Juni 2005, Indonesia untuk pertama kalinya menyelenggarakan Pilkada secara langsung sesuai dengan Undang-Undang Nomor 32 Tahun 2004 tentang Pemerintahan Daerah. Hal ini memberi ruang partisipasi politik yang lebih luas lagi bagi masyarakat.

Sudah ada beberapa penelitian yang mengkaji tentang partisipasi politik masyarakat dalam Pilkada. Partisipasi politik masyarakat dalam menentukan pilihannya di Pilkada banyak dipengaruhi oleh berbagai macam faktor baik dari media, karakteristrik pribadi, karakteristik sosial atau lingkungan sekitar, ada atau tidak ada tekanan yang diterima pemilih mejadikan pemilih lebih bebas dalam menentukan pilihan, dan yang terakhir adalah peran serta KPUD yang total dalam melakukan sosialisasi (Damita, Batubara, dan Hady 2014; Wardhani 2018). Faktor lain yang mempengaruhi partisipasi politik antara lain faktor lingkungan pendidikan, pemilih merupakan penduduk asli setempat, jumlah TPS yang banyak dan dekat dengan pemukiman warga, rasa ingin tahu dari pemilih pemula, kesadaran politik yang tinggi untuk mensukseskan pemilihan (Usfinit, Suprojo, dan Setyawan 2014).

Faktor-foktor tersebut mempengaruhi pertimbangan masyarakat untuk menentukan pasangan calon yang akan mereka pilih dalam Pemilu maupun Pilkada. Perilaku memilih calon pemimpin merupakan bentuk partisipasi politik yang paling elementer karena merupakan tindakan seorang warga yang dilakukan secara sukarela untuk mensukseskan jalannya pemilu sampai akhirnya diharapakan menghasilakan pemimpin yang bisa menelurkan kebijakan-kebijakan publik yang berpihak pada masyarakat. Untuk menghasilkan pemimpin atau calon legislatif diperlukan rekrutmen yang kader partai politik (parpol) yang professional dan dikenal masyarakat ini pun menjadi salah satu faktor masyarakat bersemangat dalam berpartisipasi (Liando 2016).

Perilaku politik masyarakat dapat berubahubah tergantung pada preferensi yang melatarbelakanginya. Pemilihan Gubernur dan Wakil Gubernur Jawa Tengah serta Pemilihan Bupati dan Wakil Bupati Kudus yang diselenggarakan pada 27 Juni 2018 telah berlangsung 
secara aman, damai, dan tertib. Pada pemilihan Bupati dan Wakil Bupati Kabupaten Kudus terdapat partisipasi pemilih yang cukup signifikan, yaitu sebesar 84,26\% (KPUD Kab. Kudus, 2018).

Penyelenggaraan Pilkada Kabupaten Kudus 2018 dikatakan berhasil dengan indikator di antaranya: 1) masyarakat dapat menggunakan hak pilihnya dengan bebas, aman, dan nyaman; 2) terlayaninya disabilitas dalam Pilkada; 3) terjaminnya kualitas SDM Penyelenggara dalam pelaksanaan Pilkada; 4) tingginya tingkat partisipasi politik masyarakat pada Pilkada; 5) Kontestan dan publik taat pada asas dan peraturan perundang-undangan Pilkada; 6) minimnya konflik horizontal dan gugatan Pilkada; 7) masyarakat siap menerima dan mendukung apapun hasil Pilkada; serta 8) menghasilkan kepala daerah yang berkualitas dan sesuai harapan masyarakat (KPUD Kab. Kudus, 2018).

Secara kuantitas, angka partisipasi sebesar 84,26\% merupakan angka yang cukup menggembirakan karena hal tersebut dapat menjadi salah satu indikator kesadaran masyarakat Kudus untuk memilih pemimpinnya di mana ini menjadi langkah awal untuk menentukan arah kebijakan politik di masa yang akan datang. Namun dengan melihat kuantitas saja, para pelaku politik tidak bisa secara komperehensif memahami perilaku politik pemilih. Ada berbagai macam preferensi yang mendorong pemilih memilih pasangan calon tertentu. Ini adalah hal menarik untuk diteliti, penelitian ini berbeda dengan penelitian sebelumnya mengkaji tentang partisipasi politik. Perilaku pemilih dalam berpartisipasi pada PILKADA
Kabupaten Kudus Tahun 2018 akan dilihat dari tiga pendekatan yakni sosiologis, psikologis, dan rasional sehingga penelitian ini akan memberikan distingsi dari penelitian yang sudah dilakukan sebelumnya. Penelitian ini akan dikaji melalui "metode deskriptif" dengan usaha pencarian fakta interpretasi yang tepat yang digunakan untuk mempelajari masalahmasalah dalam masyarakat, serta tata cara yang berlaku dalam masyarakat serta situasisituasi tertentu, termasuk hubungan kegiatan, sikap, pandangan, serta proses-proses yang sedang berlangsung dan pengaruh-pengaruh dari suatu fenomena (Nazir 1998: 64).

Penelitian ini adalah penelitian kualitatif. Metode kualitatif ini akan digunakan untuk menganalisis fenomena perilaku pemilih untuk mendongkrak partisipasi pemilih dalam Pilkada Kabupaten Kudus tahun 2018.

Diperlukan data yang valid untuk sebuah penelitian ilmiah. Data penelitian ini, diperoleh dengan melakukan wawancara secara langsung kepada 37 informan yang tersebar di seluruh kecamatan di Kabupaten Kudus. Data informan ini diacak secara seksama guna menemukan tingkat varian partisipasi pemilih pada setiap informan yang diambil. Secara seksama, para informan dipilih dari semua struktur sosial yang ada di masyarakat, mulai dari pendidik, pemilih pemula, pelajar, buruh, pedagang, dan tokoh masyarakat.

Teknik pengumpulan data dalam penelitian kualitatif ini menggunakan data primer dan sekunder. Untuk data primer, peneliti melakukan in-depth interview terhadap lembagalembaga yang berkaitan dengan penyeleng- 
garaan Pilkada, antara lain KPUD, partai politik, media massa, dan civil society. Secara garis besar, data dalam interview ini dilakukan dengan pemilihan informan yang tercakup ke dalam 9 kecamatan di Kabupaten Kudus. Peneliti juga akan melakukan indepth interview terhadap masyarakat umum dengan karakteristik sosial yang berbeda. Pengumpulan data lapangan pada penelitian ini, dilakukan pada bulan Agustus 2018 dalam rentang waktu satu bulan pelaksanaan penelitian sampai pelaporannya.

Data sekunder penelitian diperoleh melalui telaah kepustakaan dari buku-buku, literatur, dokumen, artikel, jurnal ilmiah dan berbagai sumber yang berhubungan dengan penelitian ini tentang perilaku pemilih dalam rangka mendongkrak partisipasi pada Pilkada 2018 di Kabupaten Kudus.

Penelitian ini menggunakan teknik analisis kualitatif sebagai prosedur penelitian yang menghasilkan data deskriptif.

\section{Partisipasi Politik}

Partisipasi politik memiliki pengertian yang beragam. Ada beberapa ahli yang mengungkapkan pendapatnya tentang partisipasi politik. Menurut Ramlan Surbakti (2007: 140) yang dimaksud dengan partisipasi politik adalah keikutsertaan warga negara biasa dalam menentukan segala keputusan yang menyangkut atau memengaruhi hidupnya.

Damsar (2015: 180) mengutip pendapat Herbert McClosky, bahwa partisipasi politik adalah kegiatan-kegiatan sukarela dari warga masyarakat melalui mana mereka mengambil bagian dalam proses pemilihan penguasa, dan secara langsung atau tidak langsung, dalam proses pembentukan kebijakan umum.

Menurut Ramlan Surbakti partisipasi politik terbagi menjadi dua yaitu partisipasi aktif dan pasrtisipasi pasif. Partisipasi aktif adalah mengajukan usul mengenai suatu kebijakan umum, mengajukan alternatif kebijakan umum yang berlainan dengan kebijakan yang dibuat pemerintah, mengajukan kritik dan perbaikan untuk meluruskan kebijakan, membayar pajak dan memilih pemimpin pemerintah. Sebaliknya, kegiatan yang termasuk dalam kategori partisipasi pasif berupa kegiatan-kegiatan yang menaati pemerintah, menerima, dan melaksanakan saja setiap keputusan pemerintah (Surbakti 2007: 142).

Sementara itu, Milbart dan Goel membedakan partisipasi menjadi beberapa kategori. Pertama, apatis, artinya orang yang tidak berpartisipasi dan menarik diri dari proses politik. Kedua, spectator artinya orang yang setidaktidaknya pernah ikut memilih dalam pemilihan umum. Ketiga, gladiator artinya mereka yang secara aktif terlibat dalam proses politik, yakni komunikator, spesialis mengadakan kontak tatap muka, aktivis partai dan pekerja kampanye, dan aktivis masyarakat (Surbakti 2007: 143).

\section{Perilaku Politik}

Perilaku politik merupakan sikap politik seseorang terhadap objek politik yang terwujud dalam tindakan atau aktivitas politik seseorang. Sudijono Sastroatmodjo menyatakan bahwa perilaku politik adalah tindakan 
yang dilakukan oleh pemerintah ataupun masyarakat berkaitan dengan tujuan suatu masyarakat, kebijakan untuk mencapai suatu tujuan, serta sistem kekuasaan yang memungkinkan adanya suatu otoritas untuk mengatur kehidupan masyarakat ke arah pencapaian tujuan tersebut. Dari pengertian ini perilaku politik lebih diarahkan pada tercapainya konsensus untuk mencapai tujuan dari masyarakat dan pemerintah. Diungkapkan pula oleh Sudijono bahwa perilaku politik bukanlah sesuatu yang berdiri sendiri tetapi mengandung ketertarikan dengan hal-hal lainnya (Sastroatmojo 1995: 56).

Ramlan Surbakti memandang perilaku politik sebagai kegiatan yang berkenaan dengan proses pembuatan dan pelaksanaan keputusan politik. Dengan demikian perilaku politik merupakan tindakan masyarakat atau pemerintah yang berkaitan dengan kepentingan atau pencapaian tujuan terkait keputusan politik baik dalam proses pembuatan maupun pelaksanaannya. Sebagai insan politik setiap warga negara tentunya melakukan tindakan politik, yang dalam penelitian ini lebih difokuskan pada perilaku pemilih yang juga merupakan bagian dari perilaku politik (Surbakti 1997: 19).

\section{Perilaku Pemilih}

Konsep perilaku pemilih sebagaimana yang diungkapkan oleh J. Kristiadi (1996: 76) adalah keterikatan seseorang untuk memberikan suara dalam proses pemilihan umum berdasarkan faktor psikologis, faktor sosiologis, dan faktor rasional pemilih (voting behavioral theory). Menurut A.A. Oka Mahendra (2005:
75) perilaku pemilih adalah tindakan seseorang ikut serta dalam memilih orang, partai politik atau isu publik tertentu. Dari konsep yang dikemukakan di atas, dapat dipahami bahwa perilaku pemilih merupakan tindakan pemilih terkait pemilihan langsung.

Ramlan Surbakti memandang perilaku pemilih merupakan bagian dari perilaku politik yang menggambarkan keikutsertaan warga negara dalam pemilu yang juga menjadi serangkaian kegiatan membuat keputusan yakni memilih atau tidak, dan jika memilih apakah memilih kandidat $\mathrm{X}$ atau kandidat $\mathrm{Y}$ ? Berdasarkan definisi-definisi tersebut, maka dapat disimpulkan bahwa perilaku pemilih merupakan tindakan seseorang untuk memberikan suara dalam pemilihan umum, di mana yang menjadi perhatian adalah mengapa seorang pemilih memilih partai tertentu atau kandidat tertentu dan bukan partai lainnya atau kandidat lainnya (Surbakti 1997).

\section{Pendekatan Perilaku Pemilih}

Pembagian pendekatan perilaku pemilih secara umum terbagi menjadi tiga, yaitu pendekatan sosiologis, pendekatan psikologis, dan pendekatan rasional. Dalam pendekatan sosiologis pada dasarnya menjelaskan bahwa karakteristik sosial dan pengelompokan sosial, yaitu usia, jenis kelamin, agama, pekerjaan, latar belakang, keluarga, kegiatan-kegiatan dalam kelompok formal dan informal mempunyai pengaruh yang cukup signifikan dalam pembentukan perilaku pemilih. Perbedaan karakteristik masyarakat yang berbeda ini membentuk persepsi, sikap, keyakinan, dan 
sikap politik dari masing-masing individu (Khoirudin 2004: 96). Pemilih akan cenderung memilih partai atau tokoh tertentu karena ada kesamaan karakteristik sosial antara pemilih dan partai atau tokoh yang dipilih (Mahendra 2005: 75).

Pendekatan psikologis merupakan pendekatan yang melihat perilaku pemilih sebagai bentukan dari proses sosialisasi yang melahirkan ikatan emosional (identifikasi) yang mengarahkan tindakan politik seseorang dalam suatu pemilihan. Proses sosialisasi yang panjang yang membentuk ikatan yang kuat dengan partai politik dan menimbulkan identifikasi tanpa disadari (Nursal 2004: 59-60). Identifikasi merupakan dorongan untuk identik dengan orang lain yang dilakukan seseorang terhadap orang lain yang dianggapnya ideal dalam suatu segi. Sehingga faktor ketokohan juga berpengaruh kuat dalam membentuk perilaku pemilih. Indikator yang digunakan untuk mengukur besarnya pengaruh pendekatan ini adalah: 1) ketokohan, dilihat dari persamaan emosional pemilih yang melandasi pilihannya dengan mempertimbangkan identitas atau ketokohan calon dan tokoh-tokoh panutan yang dihormati oleh pemilih; 2) identifikasi partai, dilihat dari kesamaan pandangan pemilih dengan anggota keluarganya terhadap pilihan tertentu.

Pendekatan rasional merupakan pendekatan yang melihat bahwa pilihan pemilih adalah keputusan rasional pemilih di mana yang dipertimbangkan adalah: 1) Orientasi visi misi yang diukur dari pengatahuan dan pemahaman serta ketertarikan pemilih terhadap program yang ditawarkan oleh calon; 2) Orientasi
Kandidat yang diukur dari kualitas kandidat meliputi kedudukan, informasi, prestasi dan popularitas pribadi bersangkutan dalam berbagai bidang kehidupan terkait kompetensinya dalam merealisasikan program yang ditawarkan. Pengaruh isu dan kandidat itu antara lain berkaitan erat dengan peristiwa sosial, ekonomi dan politik tertentu yang kontekstual dengan pemilihan yang bersangkutan, sementara pendekatan rasional terhadap kandidat bisa didasarkan pada kedudukan, informasi, prestasi dan popularitas pribadi bersangkutan dalam berbagai bidang kehidupan. Kualitas kandidat memiliki dua variabel, yakni kualitas instrumental yaitu tindakan yang diyakini pemilih akan direalisasikan oleh kandidat bila telah menang dalam pemilihan, dan variabel kualitas simbolik, yaitu kualitas kepribadian seseorang yang berkaitan dengan integritas diri, ketegasan, ketaatan pada norma dan aturan, kebaikan, sikap merakyat dan sebagainya.

\section{Pemilihan Kepala Daerah (Pilkada) Kabupaten Kudus}

Pemilihan kepala daerah secara lebih demokratis dimulai pasca runtuhnya rezim orde baru. Pada masa orde baru, presiden memiliki kewenangan dan kontrol penuh terhadap penetapan kepala daerah. DPRD merekomendasikan calon kepala daerah tersebut kepada presiden, namun presiden mempunyai penilaian sendiri dengan syarat-syarat tertentu yang telah ditetapkan oleh presiden. Pada era reformasi, pemerintah menyusun UU Nomor 22 Tahun 1999 mengenai penyelenggaraan pemerintah di daerah. Dalam UU ini, wewe- 
nang penuh pemilihan Kepala Daerah berada di tangan DPRD. Namun dalam perjalannya, banyak terjadi praktek membeli suara anggota DPRD untuk menjadi pemenang dalam Pilkada. Untuk itu pada tahun 2004 terbit UU Nomor 32 Tahun 2004 yang mengatur Pilkada secara langsung.

Pemilihan kepala daerah secara langsung ini menjadi mekanisme baru dalam demokrasi di Indonesia di mana masyarakat di suatu daerah memilih langsung kepala daerahnya. Hal ini diharapkan agar masyarakat lebih memahami kandidat kepala daerah dan memilih kandidat yang visi misinya sesuai dengan kebutuhan daerah. Dengan adanya Pilkada ini berarti bahwa partisipasi politik masyarakat menjadi semakin luas. Kesempatan ini hendaknya disertai dengan pendidikan politik kepada masyarakat sehingga timbul kesadaran politik yang akan berdampak positif pada terwujudnya kepemimpinan daerah yang mengemban amanah rakyat dengan baik.

Pilkada di Kabupaten Kudus diselenggarakan pada 27 Juni 2018 lalu terdiri dari pemilihan Gubernur-Wakil Gubernur Jawa Tengah dan Bupati-Wakil Bupati Kabupaten Kudus. Pasangan calon yang bertanding dalam arena Pilkada dapat dilihat pada Tabel 1.

\section{Perolehan Suara Pemilihan Kepala Daerah (Pilkada) Kabupaten Kudus}

Hak memilih dalam penyelenggaraan pemilihan kepala daerah dan pemilihan umum merupakan hak dasar setiap warga Negara yang dijamin oleh konstitusi. Partisipasi pemilih sebagai hak asasi manusia juga tercantum dalam Deklarasi Universal Hak Asasi
Manusia Pasal 21 Ayat (1)-(3) Deklarasi Universal Hak-Hak Asasi Manusia (DUHAM) Tahun 1948 melalui resolusi 217 A (III) yang berbunyi:

Setiap orang berhak turut serta dalam pemerintahan negaranya, secara langsung atau melalui wakil-wakil yang dipilih dengan bebas. 1) Setiap orang berhak atas kesempatan yang sama untuk diangkat dalam jabatan pemerintahan negaranya. 2) Kehendak rakyat harus menjadi dasar kekuasaan pemerintah; kehendak ini harus dinyatakan dalam pemilihan umum yang dilaksanakan secara berkala dan murni, dengan hak pilih yang bersifat umum dan sederajat, dengan pemungutan suara secara rahasia ataupun dengan prosedur lain yang menjamin kebebasan memberikan suara. (Majelis Umum PBB 1948)

Berdasarkan pasal di atas maka tidak dibenarkan adanya tindakan represi dan intimidasi kepada masyarakat yang mempunyai hak pilih untuk kepentingan golongan tertentu. Negara harus menjamin masyarakat bisa menggunakan hak pilihnya dengan bebas dan rasional, sehingga cita-cita demokrasi dapat tercapai. Memilih calon pemimpin adalah bentuk kontribusi dan partisipasi rakyat untuk berperan aktif dalam penyelenggaraan pemerintahan. Peran aktif masyarakat ini yang sangat menentukan bagaimana sosok pemimpin yang bisa mewujudkan pemerintahan yang adil yang sesuai dengan harapan dan citacita rakyat.

Berdasarkan survei dari Komisi Pemilihan Umum (KPUD) Kudus, tingkat partisipasi pemilih dalam Pilkada tanggal 27 Juni 2018 menunjukkan angka yang menggembirakan, di mana antusiame pemilih sebesar $84,26 \%$ dari 
daftar pemilih tetap sebanyak 611.879 jiwa dan total jumlah penduduk Kabupaten Kudus 861.430 (BPS Kab. Kudus). Ini berarti ada 15, 74 $\%$ daftar pemilih tetap yang terdaftar di KPU tidak menggunakan hak pilihnya yaitu sebanyak 91.290 jiwa tidak hadir ke TPS dan memberikan suaranya ketika Pilkada. Ketidakhadiran pemilih bisa disebabkan oleh beberapa faktor dan kendala tertentu, seperti pemilih berada di luar kota ketika hari pencoblosan; pemilih dalam kondisi sakit; pemilih sudah meninggal dunia; pemilih belum mempunyai kesadaran politik sehingga bersikap apatis, pemilih memutuskan untuk tidak memilih karena pertimbangan tertentu dan atau ada pertimbangan lain yang membuat pemilih memutuskan tidak datang ke TPS untuk mencoblos atau menggunakan hak pilihnya.

Jumlah DPT yang menggunakan hak pilihnya sebanyak 520.589 jiwa dengan rincian 473.595 suara sah dan 46.994 suara tidak sah dalam pemilihan Gubernur-Wakil Gubernur Jawa Tengah sedangkan untuk pemilihan Bupati-Wakil Bupati Kabupaten Kudus terdapat 503.419 suara sah dan 16.891 suara tidak sah. Suara tidak sah sebagian besar diakibatkan oleh kesalahan saat mencoblos di kertas suara. Dalam Pilkada Kabupaten Kudus, KPU menyiapkan tempat pemungutan suara sebanyak 1.491 yang tersebar di 123 desa di seluruh Kabupaten Kudus.

Data pada Tabel 2. dapat dilihat bahwa bahwa pasangan calon independen Noor Hartoyo-Junaidi dan Akhwan-Hadi Sucipto memperoleh suara yang relatif lebih kecil di seluruh kecamatan dibandingkan dengan pasangan calon lainnya. Noor Hartoyo-Junaidi memiliki jumlah suara paling kecil, di mana di Kecamatan Undaan jumlah suaranya hanya mencapai 474 suara. Pasangan Sri HartiniSetia Budi Wibowo mendapatkan suara yang lebih besar dibandingkan dengan pasangan

Tabel 1.

Pasangan Bupati-Wakil Bupati Kabupaten Kudus 2018

\begin{tabular}{|c|c|c|c|c|}
\hline \multirow{2}{*}{$\begin{array}{l}\text { No } \\
\text { Urut }\end{array}$} & \multicolumn{2}{|c|}{ Pasangan Calon } & \multirow{2}{*}{$\begin{array}{c}\text { Partai } \\
\text { Pengusung }\end{array}$} & \multirow{2}{*}{ Visi } \\
\hline & Calon Bupati & Calon Wakil Bupati & & \\
\hline 1 & $\begin{array}{l}\text { Masan, S.E., MM. } \\
\text { (Anggota DPRD Kudus 2014- } \\
\text { 2019) }\end{array}$ & $\begin{array}{l}\text { Drs. H. Noor Yasin, MM. } \\
\text { (Sekretaris Daerah Kudus } \\
\text { 2012-sekarang) }\end{array}$ & $\begin{array}{l}\text { Demokrat } \\
\text { PAN, Golkar } \\
\text { PDI-P }\end{array}$ & $\begin{array}{l}\text { "Bersama Membangun } \\
\text { Kudus Lebih Baik." }\end{array}$ \\
\hline 2 & $\begin{array}{l}\text { H. Noor Hartoyo, SH. (Wakil } \\
\text { Ketua DPRD Kudus 2009- } \\
\text { 2014) }\end{array}$ & $\begin{array}{l}\text { Junaidi, SH. (Staf } \\
\text { Pemerintahan Kelurahan } \\
\text { Mlati Norowito Kudus) }\end{array}$ & Independen & $\begin{array}{l}\text { "Terwujudnya Seluruh } \\
\text { Masyarakat Kudus yang } \\
\text { Berperadaban dan } \\
\text { Sejahtera." }\end{array}$ \\
\hline 4 & $\begin{array}{l}\text { H. Akhwan, S.H. (Anggota } \\
\text { DPRD Propinsi Jawa Tengah } \\
\text { Periode 2004-2009) }\end{array}$ & $\begin{array}{l}\text { H. Hadi Sucipto, S.Pd., MM. } \\
\text { (Kepala Dinas Perindustrian, } \\
\text { Koperasi, UMKM Kudus } \\
\text { Tahun 2015) }\end{array}$ & Independen & $\begin{array}{l}\text { "Terwujudnya Kudus } \\
\text { Makmur Bermatabat." }\end{array}$ \\
\hline 5 & $\begin{array}{l}\text { Ir. H. Muhammad Tamzil, MT. } \\
\text { (Bupati Kudus Periode 2003- } \\
\text { 2008) }\end{array}$ & $\begin{array}{l}\text { HM Hartopo, ST, MM, MH. } \\
\text { (Anggota DPRD Kudus } \\
\text { Periode 2014-2019) }\end{array}$ & $\begin{array}{l}\text { Hanura } \\
\text { PPP } \\
\text { PKB }\end{array}$ & $\begin{array}{l}\text { "Kudus Bangkit Menuju } \\
\text { Kabupaten Modern, } \\
\text { Religius, dan Sejahtera." }\end{array}$ \\
\hline
\end{tabular}

Sumber: Komisi Pemilihan Umum Daerah (KPUD) Kabupaten Kudus, 2018 
calon independen. Suara terbanyak bagi pasangan ini adalah di Kecamatan Gebog, dilanjutkan dengan Kecamatan Dawe.

Ada dua pasangan calon yang mendominasi jumlah suara, yaitu Masan-Noor Yasin dan Tamzil-Hartopo. Kedua pasangan ini saling mengungguli di beberapa kecamatan. Pasangan Masan-Noor Yasin mengungguli pasangan Tamzil-Hartopo di Kecamatan Kaliwungu, Kecamatan Jati, Kecamatan Undaan, dan Kecamatan Mejobo. Sementara di lima kecamatan lainnya pasangan Tamzil-Hartopo lebih unggul. Suara terbanyak bagi pasangan Tamzil-Hartopo adalah di Kecamatan Jekulo.

\section{Dinamika Pemilih dalam Pilkada Kudus 2018}

\section{Pemilih Kategori Sosiologis}

Pemilihan umum merupakan pesta demokrasi periodik yang memberikan warna dan dinamika sosial yang mengelitik dan terkadang menegangkan. Masyarakat dituntut untuk menjadi pemilih yang cerdas, mereka harus bisa membedakan mana calon yang mau bekerja dengan hati atau hanya umbar janji pada pemilih. Pemilih adalah warga negara Indonesia yang sudah genap berumur 17 (tujuh belas) tahun atau lebih, sudah kawin, atau sudah pernah kawin (Undang-undang No. 7 Tahun 2017 tentang Pemilu, Bab 1, pasal 34). Pemilih bagian yang tidak bisa dipisahkan dengan proses jalannya Pemilu, suara merekalah yang menentukan menang atau tidak calon atau pasangan calon, maka dari itu para calon dan pasangan calon harus bisa merayu dan meyakinkan pemilih untuk memilih mereka. Upaya dan strategi yang dilakukan pasangan calon lewat kampanye atau sosialisasi dengan berbagai macam media, menjadi salah satu cara yang bisa dilakukan pasangan calon untuk mendulang banyak suara. Strategi dalam bentuk apapun dikatakan sah jika masih sesuai dengan syarat dan ketentuan yang ditetapkan

Tabel 2.

Rincian Perolehan Calon Bupati dan Wakil Bupati Kabupaten Kudus Tahun 2018 per Kecamatan

\begin{tabular}{|c|c|c|c|c|c|c|c|c|c|c|c|}
\hline No. & PASLON & Kaliwungu & Kota & Jati & Undaan & Mejobo & Jekulo & Bae & Gebog & Dawe & $\begin{array}{l}\text { Jumlah } \\
\text { Akhir }\end{array}$ \\
\hline 1 & $\begin{array}{l}\text { Hasan } \\
\text { Noor Yasin }\end{array}$ & 27.889 & 16.646 & 27.241 & 23.291 & 17.681 & 25.444 & 13.392 & 17.014 & 25.495 & 194.093 \\
\hline 2 & $\begin{array}{l}\text { Noor Hartoyo } \\
\text { Junaidi }\end{array}$ & 581 & 1.083 & 1,078 & 478 & 1.136 & 699 & 575 & 929 & 834 & 7.393 \\
\hline 3 & $\begin{array}{l}\text { Sri Hartini } \\
\text { Setia Budi } \\
\text { Wibowo }\end{array}$ & 8.020 & 7.175 & 7.235 & 4.490 & 10.294 & 7.908 & 5.902 & 14.741 & 11.027 & 76.792 \\
\hline 4 & $\begin{array}{l}\text { Ikhwan } \\
\text { Hadi Sucipto }\end{array}$ & 1.287 & 1.495 & 1.658 & 474 & 888 & 1.344 & 1.879 & 1.308 & 818 & 11.151 \\
\hline 5 & $\begin{array}{l}\text { H. Tamzil } \\
\text { Hartopo }\end{array}$ & 22.565 & 24.923 & 25.530 & 20.127 & 17.144 & 31.476 & 20.155 & 25.109 & 26.961 & 213.990 \\
\hline \multicolumn{2}{|c|}{ Suara sah } & 60.342 & 51.322 & 62.742 & 48.860 & 47.143 & 66.871 & 41.903 & 59.101 & 65.135 & 503.419 \\
\hline \multicolumn{2}{|c|}{ Suara Tidak Sah } & 2.042 & 2.183 & 2.389 & 1.279 & 1.327 & 1.991 & 1.570 & 2.008 & 2.002 & 18.891 \\
\hline \multicolumn{2}{|c|}{ Seluruh Suara } & 62.384 & 53.505 & 65.131 & 50.139 & 48.470 & 68.862 & 43.473 & 61.189 & 67.157 & 520.310 \\
\hline
\end{tabular}

Sumber: Komisi Pemilihan Umum Daerah (KPUD) Kabupaten Kudus, 2018 
KPU. Respon balik pemilih dari kampanye yang dilakukan oleh pasang calon (paslon) yakni dengan menentukan pilihan untuk memilih atau tidak. Hak pemilih dilindungi oleh undang-undang.

Perilaku pemilih dalam proses menentukan pilihan politik, menurut J. Kristiadi (1996: 76) dipengaruhi oleh tiga faktor atau pendekatan yaitu pendekatan sosiologis, psikologis dan logika. Pendekatan tersebutlah fokus dari penelitian ini. Data dan informasi dari penelitian ini digali dari beberapa informan. Berikut adalah perilaku pemilih dalam pendekatan sosiologis. Pertama, pendekatan sosiologis menurut Kristiadi difokuskan pada karakteristik sosial dan pengelompokan sosial, yaitu usia, jenis kelamin, agama, pekerjaan, latar belakang, keluarga, kegiatankegiatan dalam kelompok formal dan informal mempunyai pengaruh yang cukup signifikan dalam pembentukan perilaku pemilih. Perilaku pemilih sesuai pendekatan sosiologis pada Pilkada Kabupaten Kudus dilihat dari pengelompokan usia, pekerjaan dan penyandang disabilitas yang digali dari informan menunjukkan bahwa perilaku pemilih berdasarkan usia (umur) memiliki kecenderungan yang berbeda antara usia remaja, dewasa, dan tua. Untuk kategori pemilih pemula atau usia remaja memiliki kecenderungan bahwa pilihan netral. Pilihan mereka biasanya tidak begitu memiliki tendensi dan ekspektasi, meskipun ada sosialisasi atau uang politik (money politic). Uang politik dan sosialisasi tidak akan berdampak signifikan dalam mempengaruhi pilihan mereka karena partisipasi mereka dalam Pilkada lebih didasari rasa penasaran pengalaman pertama (first experience) dan terkadang dipengaruhi oleh teman dari hasil diskusi group whatsapp. Hal tersebut adalah hal yang disampaikan oleh Erlin, Siti dan Nada sebagai pemilih pemula. Sehingga jadilah maklum dan tidak mengherankan jika tidak sedikit dari pemilih pemula melakukan swafoto di dalam bilik suara dan tanpa beban menggugahnya dalam group media sosial (medsos) mereka. Sekali pun pilihan mereka tidak didasari money politic, akan tetapi sebagian dari mereka memaklumi adanya money politic sebagai bentuk rizki, menurut Nada.

Tidak semua anak muda atau remaja melakukan pilihan dari nurani dan inisiatif sendiri, karena ada sebagian yang masih diarahkan oleh timsukses, seperti Rudi dan ada pula mengikuti pilihan orang tua, seperti si Erlin. Ajakan orang tua untuk memilih atau memihak salah satu pasangan calon (Paslon) bukan tanpa pertimbangan. Orang tua (orang dewasa) memiliki pemikiran yang rasional atas apa yang berkembang saat ini dari merefleksikan hal atau pengalaman sebelumnya, pertama mereka para orang tua sudah mengenal pasangan calon baik secara langsung maupun tidak, yang mana kenal pasangan calon karena pernah menjabat atau memimpin sebelumnya seperti Pak Tamzil, beliau adalah Bupati Kabupaten Kudus sebelum ini, maka mereka paham track record selama dipimpin dan ini menjadi pertimbangan untuk dipilih lagi atau ganti. Kedua, mereka merupakan bagian dari tim sukses pasangan calon, seperti yang disampaikan Erlin bahwa bapaknya adalah tim sukses 
(timses). Tim sukses biasanya adalah bagian dari orang-orang yang setia, dan memiliki komitmen kuat dengan apa yang sudah diamanahkan yaitu memilih orang yang dia dukung dan mencari dukungan untuk ikut mendukung. Ketiga, orang tua biasanya tertarik dengan tontonan yang bersingungan dengan politik yang menjadikan mereka mengetahui visi dan misi serta program kerja yang dipaparkan calon sehingga bisa menangkap pesan kampanye dengan jelas dan ini menjadi dasar memantapkan diri dalam menentukan pilihan. Pemilih seperti ini biasanya mencoblos karena menyadari sebagai warga negara yang baik. Alasan inilah yang menjadi pijakan Dewi yang seorang akademisi untuk memilih. Keempat, mendapat uang lelah (nama lain money politic menurut masyarakat) dari salah satu pasangan calon sehingga wajar saja jika mereka mengarahkan atau menggiring pilihan suara anak dan istrinya kepada salah satu pasangan calon. Kelima, memungkinkan ada hubungan saudara, ini alasan subjektif yang paling mudah diterima dan termasuk modal politik paling jelas untuk mengiring suara, jika tidak ada konflik dalam keluarga. Keenam, seagama. Alasan pemilih memilih paslon yang seiman atau seagama memang sudah umum, jadi tidak kaget jika kemudian banyak politisi yang menggunakan agama sebagai amunisi politik. Ketujuh, memiliki jenis kelamin yang sama. Alasan jenis kelamin sebenarnya tidak memiliki signifikansi sebagai dasar seseorang memilih paslon, kecuali hal itu kemudian dihubungkan dan dibungkus atas nama agama pasti akan lain ceritanya. Akan tetapi pada dasarnya orang yang memilih atas dasar kelamin adalah pemilih perempuan. Alasanalasan mengapa orang tua, atau kepala keluarga menggiring suara anak dan istrinya yang dipaparkan sebelumya merupakan bagian dari perilaku pemilih usia dewasa dan tua karena pemikiran mereka yang lebih rasiona karena hasil belajar dari pengalaman.

Selain usia yang mempengaruhi perilaku dan persepsi pemilih dalam memilih calon pasangan Pilkada Kudus, profesi atau pekerjaan pun sama. Pekerjaan adalah bagian yang tidak mudah dipisahkan dari kehidupan manusia pada umumnya. Hakikatnya orang bekerja, tidak saja untuk mempertahankan kelangsungan hidupnya, tetapi juga bertujuan untuk mencapai taraf hidup yang lebih baik (As'ad 2002: 46). Untuk mencapai taraf hidup atau kesejahteraan maka lingkungan di mana bertempat tinggal dan bekerja harus stabil secara sosial, politik dan keamanan, maka dibutuhkan pemimpin yang memiliki kompetensi unggul. Untuk memperoleh pemimpin yang memiliki kompetensi unggul maka masyarakat harus berpartisipasi dalam pemilu baik Pilkada maupun Pilpres. Dalam Pilkada Kudus, menunjukkan bahwa perilaku seorang pemilih yang dilatarbelakangi status pekerjaan atau profesi akan memilih salah pasangan calon dikarenakan pertama, pasangan calon memaparkan program kerja untuk lebih bisa mengkoodinir dan menyejahterakan profesi atau pekerjaan mereka. Kedua, salah satu pasangan calon memiliki backround profesi yang sama, sehingga dirasa lebih bisa memahami. Ketiga, memilih karena mengetahui visi dan misi, ini biasanya dilakukan oleh 
masyarakat yang memiliki profesi dengan tingkat pendidikan yang tinggi. Keempat, dipengaruhi kesadaran diri sebagai warga negara yang baik. Ini membuktikan bahwa pekerjaan atau profesi seseorang itu akan mempengaruhi perilaku seseorang dalam memilih pasangan calon dengan berbagai pertimbangan tertentu.

Hak memilih tidak hanya dimiliki oleh mereka yang secara fisik sempurna tapi bagi mereka yang dianugrahi kebutuhan khusus (disabilitas) pun punya hak sama dalam Pemilu (Pemilihan Umum). Hak mereka ini tertuang dalam Undang-Undang No. 7 Tahun 2017 tentang Pemilihan Umum, pasal 5 bahwa penyandang disabilitas yang memenuhi syarat mempunyai kesempatan yang sama sebagai pemilih, sebagai calon anggota DPR, sebagai calon anggota DPD, sebagai calon Presiden/Wakil Presiden, sebagai anggota DPRD dan sebagai peyelenggara Pemilu. Sebagai pemilih, penyandang disabilitas memiliki alasan tertentu ketika menjatuhkan pilihan pada salah satu pasangan calon dikarenakan pasangan calon tersebut dirasa memiliki perhatian terhadap penyandang disabilitas, terkhusus masalah akses pekerjaan yang selama ini belum memberikan kemudahan bagi mereka. Ini membuktikan bahwa pendekatan sosiologis mempengaruhi persepsi pemilih dalam menentukan pilihan.

\section{Pemilih Kategori Psikologis}

Beberapa perspektif dari landasan pilihan yang disampaikan oleh para informan atas ketentuan pilihannya terhadap para pasangan calon telah dikupas dalam kategori pilihan berdasarkan titik pijak sosiologis. Pada bagian yang lain, kategori pilihan masyarakat juga disandarkan kepada alasan-alasan psikologis pilihan mereka. Mengutip dalam penjelasan Koentjaraningrat, manusia memiliki sebuah dimensi kolektif dalam kehidupan mereka. Dalam perjalanannya, di saat manusia menemukan suatu tindakan yang terbukti berdayaguna dalam menanggulangi suatu masalah hidup, maka tingkah laku itu akan diulanginya lagi tatkala masalah yang sama kembali dialami (Koentjaraningrat 2011).

Berpijak kepada perspektif yang disampaikan oleh Koentjaraningrat di atas, dapat dilihat beberapa hal yang menjadikan ketentuan seorang pemilih atas pilihan dirinya kepada pasangan calon dalam Pilkada Kudus 2018 disebabkan oleh pemahaman kolektif mereka akan signifikansi pesta demokrasi ini bagi keberlangsungan hidup mereka di daerah. Pemahaman kolektif yang dibangun oleh pemilih terhadap pasangan calon tidak bisa timbul atau muncul seketika dalam waktu yang singkat karena ada proses psikologi yang menjadi bagunan dasar seseorang atau pemilih mengetahui dan kemudian memahami pasangan calon. Pendekatan psikologis di sini merupakan pendekatan yang melihat perilaku pemilih sebagai bentukan dari proses sosialisasi yang melahirkan ikatan emosional (identifikasi) yang mengarahkan tindakan politik seseorang dalam suatu pemilihan. Proses sosialisasi yang panjang yang membentuk ikatan yang kuat dengan partai politik dan menimbulkan identifikasi tanpa disadari (Nursal 2004: 59-60). Hal ini akan memberikan signifikansi prilaku pemilih 
dalam menentukan pilihan. Pendekatan psikologis masyarakat Kudus dalam Pilkada tahun 2018 digali dari informan yang bernama Rudi, Sari, Fatah, Pi'an dan Mega memperlihatkan bahwa pemilih menetukan pilihannya kepada pasangan calon karena pertama, mengetahui profil pasangan calon dari hasil sosialisasi tim sukses. Sosialisasi tim sukses biasanya tidak begitu mengena secara langsung karena sering kali hanya dalam bentuk leaflet atau pamflet kecil yang berisi foto serta visi dan misi calon. Meskipun demikian, ini masih efektif di daerah-daerah yang tidak memungkinkan untuk kampanye secara langsung. Kedua, pasangan calon adalah orang yang pernah memimpin sebelumnya, yang dalam hal ini adalah pak Tamzil. Ini adalah poin plus dan modal politik yang bagus bagi mereka yang demikian asal memiliki track record baik, maka ketokohan, nama dan wajah dari calon pasti sudah familiar di mata dan telingga masyarakat. Ketiga, memiliki background kepartaian yang sama. Pemilih yang merupakan anggota atau simpatisan dengan partai yang sama dengan pasangan calon, kemungkinan untuk tidak mendukung dan berpaling kecil. Keempat, adanya diskusi ringan tentang pasangan calon di dalam group whatshapp. Hal ini biasanya dilakukan pemilih pemula. Kelima, mendengar dari apa yang dibicarakan masyarakat sekitar tentang pasangan calon. Perilaku pemilih melalui pendekatan psikologi menunjukkan bahwa proses memahami dan mengenal pasangan calon yang mendorong pemilih memutuskan untuk memilih salah atu pasangan calon adalah proses yang tidak singkat, ada proses sosiali- sasi yang dilakukan tim sukses, memori pengalaman masa lalu dari salah satu paslon dan image yang terbangun di masyakat mempengaruhi opini sekitar, inilah yang ikut serta menguatkan pilihan. Maka ini serupa yang dipaparkan oleh Amrul bahwa bentukan perilaku pemilih melalui proses sosialisasi yang kemudian menimbulkan ikatan emosional pemilih yang mengarah tindakan politik seseorang dalam pemilihan.

\section{Pemilih Kategori Rasional}

Seorang pemilih dalam memulai dan melanjutkan pilihannya di sebuah kontes Pilkada akan sangat diilhami oleh sudut pandang dirinya terhadap pasangan calon. Dalam kondisi ini, sudut pandang entry point dirinya akan sangat berarti guna meneguhkan alternatif-alternatif pilihan yang akan diambil. Entry point merupakan sudut pandang yang berisikan pendapat, argumentasi, dan hipotesis yang dibangun oleh seseorang, yang juga sekaligus menunjukkan keterbatasannya sebagai seorang manusia, karena tak seorang pun yang dapat menggambarkan segala sesuatu secara lengkap (Syaifuddin 2015: 157). Untuk itulah, seorang pemilih dalam menetentukan pilihannya hanya akan dihadapkan kepada suatu sudut pandang yang terbatas. Sudut pandang ini bisa dilihat dari bagaimana pemilih menentukan pilihan berdasarkan pikiran yang logis dan rasional. Perilaku rasional ini terlihat dalam Pilkada Kudus, dari penggalian informasi dai beberapa informan Atika Rizki, Yanti dan yang lain, menunjukkan bahwa perilaku rasional yang menjadi landasan mereka menentukan 
pilihannya antara lain pertama ingin menjadi warga negara yang baik dengan memenuhi hak dan kewajiban yang sudah diatur oleh Undang-Undang Dasar (UUD). Inilah hal mendasar yang seharusnya dimiliki oleh pemilih sebagai bagian dari masyarakat untuk senantiasa sadar akan hak dan kewajibannya sebagai warga negara, yang salah satunya adalah ikut berpartisipasi aktif dalam memilih pemimpin yang baik untuk kemajuan bangsa melalui Pemilu. Kedua, mengetahui visi dan misi pasangan calon, baik lewat tim sukses maupun media sosial. Ini adalah strategi yang cukup efisien dan efektif dalam berkampanye dan bersosialisasi untuk memikat pemilih pemula yang suka berselancar di dunia maya. Dengan mengetahui visi dan misi serta program kerja yang dibangun oleh paslon, maka pemilih akan tahu bagaimana tujuan paslon memajukan dan mengembangkan daerahnya

Ketiga, melihat ketokohan paslon. Ketokohan calon merupakan salah satu hal yang sering dijadikan patokan masyarakat untuk menentukan pilihan. Bagi masyarakat, seorang tokoh agama atau masyarakat adalah orang yang dirasa memiliki kemampuan untuk memimpin. Ketika seorang calon sudah memiliki modal ketokohan, maka tidaklah sulit untuk mendapatkan dukungan masyarakat. Keempat, calon memiliki tingkat pendidikan yang tinggi. Masyarakat berpendapat bahwa orang yang memiliki tingkat pendidikan yang tinggi lebih berpengalaman dan visioner sehingga akan lebih tahu apa yang seharusnya dilakukan untuk memajukan daerah. Kelima, memilih yang sudah memiliki pengalaman memimpin. Orang yang sudah pernah memimpin akan lebih paham dan berpengalaman sehingga kemajuan yang diinginkan akan lebih bisa diwujudkan. Keenam, adanya uang politik (money politic), sekalipun di era yang sudah terbuka sekarang ini transaksi pembelian suara lewat uang (money politic) dalam amplop belum sepenuhnya hilang dari kebiasaan masyarakat. Ora ono duwit yo ora nyoblos, kata yang sering dilontarkan masyarakat ketika musim pemilu tiba. Bagi mereka amplop tersebut wajar sebagai ganti lelah (uang lelah), itulah rasionalitas mereka. Mereka berfikir bahwa ketika memilih calon yang memberi uang atau tidak, itu tidak akan mempengaruhi kehidupannya (bagi sebagian masyarkat yang belum paham), selain mereka juga berfikir pekewuh (sungkan) ketika tidak mencoblos padahal menerima pemberian uang dari paslon.

Dinamika pemilih Pilkada Kabupaten Kudus menunjukkan partisipasi politik yang ditunjukkan oleh masyarakat, di mana pemilih atau masyarakat ikut mengambil bagian secara langsung dalam menentukan keputusan yang akan mempengaruhi hidupnya dengan memilih pemimpin secara sukarela dan tanpa paksaan seperti yang disampaikan oleh Ramlan Surbakti (2007: 140) tentang pengertian partisipasi politik. Kesukarelaan masyarakat Kudus dilihat dari bagaimana mereka tetap menggunakan hak suara diberi atau tidak diberi amplop. Masih dari pendapat yang sama bahwa masyarakat Kabupaten Kudus tergolong melakukan partisipasi pasif 
sekaligus aktif, yakni sebagian besar masyarakat menaati keputusan yang dibuat pemerintah seperti undang-undang pemilu dan masyarakat uja berpatisipasi langsung dalam memilih pemimpin pemerintah. Meskipun demikian tidak menafikkan bahwa ada 15, 74 $\%$ daftar pemilih tetap dari KPU Kabupaten Kudus yang tidak menggunakan hak suaranya. Masyarakat model seperti ini menurut Milbart dan Goel dalam Ramlan termasuk dalam partisipasi apatis (Surbakti 2007: 143). Mereka adalah orang yang tidak berpartisipasi dan menarik diri dari proses politik. Meskipun partisipasi pemilih tidak penuh dalam arti $100 \%$ akan tetapi keikutsertaan penyandang disabilitas dalam menggunakan haknya seperti masyarakat umumnya adalah hal yang juga membanggakan dari sebelumnya yang kurang diakomodir. Partisipasi pemilih memang tidak sepenuhnya didasari oleh nurani sendiri, ada suara yang mobilisasi dan dipengaruhi uang, dan atau mungkin ikut-ikut semata, akan tetapi diluar itu semua masih banyak orang yang tidak terpengaruh dengan uang politik atau amplop pemberian paslon, dengan tidak mencoblosnya walaupun uang diterima. Meskipun itu bukanlah cara yang bijak, akan tetapi ini bagian pembelajaran bagi paslon curang yang membagi-bagi uang.

\section{Kecenderungan Perilaku Pemilih pada Pemilihan Kepala Daerah Kabupaten Kudus 2018}

Pada pembahasan di atas telah diuraikan bentuk partisipasi pemilih, yaitu partisipasi otonom dan partisipasi mobilisasi. Mayoritas pemilih sudah mempunyai kesadaran politik dan berpartisipasi secara otonom dalam Pilkada Kabupaten Kudus 2018 sehingga tingkat partisipasi pemilih dalam Pilkada tanggal 27 Juni 2018 lalu menunjukkan angka yang menggembirakan, yaitu sebesar 84,26\% dengan hasil perolehan suara sebagaiman tertera pada Tabel 3.

Pemilih pemula menunjukkan semangat berpolitik dengan ikut serta dalam pemilihan kepala daerah. Hal ini merupakan indikasi positif tumbuhnya kesadaran politik pada generasi muda. Meskipun kesadaran politik sudah tumbuh baik di kalangan masyarakat, tapi masih selalu ada upaya mobilisasi pemilih untuk mendulang suara paslon tertentu. Mobilisasi itu antara lain berbentuk pembagian amplop, kampanye terselubung, maupun himbauan-himbauan di lingkungan pekerjaan, kegiatan keagamaan, komunitas, dan lain-lain. Sebagian besar pemilih mengaku mendapatkan amplop dari beberapa paslon. Jumlah amplop tersebut diberikan berdasarkan jumlah pemilih di suatu keluarga.

Mobilisasi dalam bentuk pembagian amplop ini menjadi alat paslon untuk mendulang jumlah suara. Hal ini sudah membudaya dan masih sulit untuk ditinggalkan baik oleh paslon maupun pemilih. Mereka memandang hal tersebut sebagai transaksi yang saling menguntungkan. Pemilih menganggap uang dari paslon itu sebagai uang ganti transport, uang ganti seminar, ataupun 'rejeki dadakan'. Jadi pemilih dengan tidak ada beban apapun menerima amplop itu, karena sudah dianggap lumrah oleh masyarakat. Dari hasil penelitian, 
Tabel 3.

Perolehan Calon Bupati dan Wakil Bupati Kabupaten Kudus Tahun 2018

\begin{tabular}{|c|c|c|}
\hline No. & Nama Pasangan Calon & Jumlah Akhir \\
\hline 1 & $\begin{array}{l}\text { Masan } \\
\text { Noor Yasin }\end{array}$ & 194.093 \\
\hline 2 & $\begin{array}{l}\text { Noor Hartoyo } \\
\text { Junaidi }\end{array}$ & 7.393 \\
\hline 3 & $\begin{array}{l}\text { Sri Hartini } \\
\text { Setia Budi Wibowo }\end{array}$ & 76.792 \\
\hline 4 & $\begin{array}{l}\text { Akhwan } \\
\text { Hadi Sucipto }\end{array}$ & 11.151 \\
\hline 5 & $\begin{array}{l}\text { Muhammad Tamzil } \\
\text { Hartopo }\end{array}$ & 213.990 \\
\hline \multicolumn{2}{|c|}{ Suara Sah } & 503.419 \\
\hline \multicolumn{2}{|c|}{ Suara Tidak Sah } & 18.891 \\
\hline \multicolumn{2}{|c|}{ Seluruh Suara } & 520.310 \\
\hline
\end{tabular}

Sumber: KPUD Kabupaten Kudus, 2018

peneliti menemukan bahwa tidak semua pemilih yang mendapatkan amplop lantas memilih paslon tersebut. Mereka mempunyai preferensi sendiri terhadap paslon. Jadi, amplop yang diberikan paslon mereka terima, tapi mereka tidak memilih paslon tersebut. Ada juga yang kebetulan pemberi amplop adalah paslon yang ingin dia pilih, sehingga tidak ada beban ketika mencoblos. Namun ada juga pemilih yang menggunakan hak pilihnya karena mendapatkan amplop. Jadi ketika tidak ada edaran amplop mereka tidak bersedia memberikan suaranya. Hal ini terjadi pada pemilih yang belum teredukasi atau mempunyai keterbatasan sehingga kesadaran politik belum tumbuh.

Sementara dalam hal perilaku pemilih, ada tiga pendekatan terhadap pemilih dalam menentukan pilihannya yang digunakan dalam penelitian ini, yaitu pendekatan sosiologis, pendekatan psikologis, dan pendekatan rasional. Dalam pendekatan sosiologis, peri- laku pemilih lebih banyak dipengaruhi oleh pendapat lingkungannya tentang paslon tertentu, baik karena dipengaruhi oleh lingkungan keluarga, lingkungan pertemanan atau komunitas, lingkungan pergaulan, serta dari tim sukses paslon. Pengaruh lingkungan ini yang menjadi acuan dan pertimbangan pemilih dalam memilih paslon. Selain pengaruh lingkungan, agama juga menjadi faktor pertimbangan pemilih dalam menentukan pilihannya. Sementara dalam pendekatan psikologis, pemilih melihat ketokohan dari paslon. Ketokohan itu dilihat dari kontribusi, dukungan, dan perilaku paslon terhadap dirinya, sehingga tokoh ini sangat melekat pada pemilih tersebut. Alasan psikologis lainnya dari perilaku pemilih adalah adanya ketertarikan terhadap partai tertentu sehingga paslon yang didukung tersebut menjadi paslon yang dia pilih. Pemilih ini lebih dulu mengidentifikasi dari partai pendukung, baru kemudian pasangan calonnya. Sementara 
dalam pendekatan rasional, beberapa pemilih sudah mulai mencari tahu apa visi dan misi paslon. Meskipun sosialisasi sudah dilakukan secara massif oleh KPUD Kudus, namun banyak juga pemilih yang belum paham terhadap visi misi. Pemilih lebih melihat kepada program-program yang ditawarkan oleh paslon melalui kampanye-kampanye baik secara langsung atau melalui media.

Dari pendekatan perilaku pemilih di atas, yang paling sering digunakan dalam perilaku memilih adalah pendekatan sosiologis. Meskipun sebagian besar pemilih mengatakan memilih paslon karena kinerjanya sebagai Bupati Kabupaten Kudus tahun 2003-2008, namun keputusan itu belum sepenuhnya didukung oleh pengetahuan akan visi misi dan program kerja paslon. Bagi paslon dewasa, pengalaman Ir. Muhammad Tamzil sebagai Bupati Kabupaten Kudus tahun 2003-2008 menjadi pertimbangan untuk memilih lagi beliau menjadi Bupati. Mereka merasakan dampak baik ketika beliau menjabat sebagai Bupati dulu sehingga pemilih berharap beliau akan melanjutkan kerja yang dulu tertunda, lebih punya pengalaman memimpin, serta mengetahui kondisi masyarakat Kudus. Namun bagi generasi muda, kinerja Ir. Muhammad Tamzil pada kepemimpinan terdahulu tidak bisa menjadi indikator dalam memilih, karena kondisi pemilih pemula atau pemilih muda pada saat Ir. Muhammad Tamzil memimpin belum bisa dirasakan atau dinilai oleh generasi muda karena usia pada saat itu. Generasi muda dan lansia lebih cenderung menilai berdasarkan pendapat lingkungan, keluarga, komunitas maupun tim sukses paslon.

\section{Kesimpulan}

Kesimpulan dari hasil penelitian yang dilakukan peneliti adalah: Pertama, pendekatan sosiologis. Faktor ini yang paling mempengaruhi pada model perilaku pemilih karena pemilih cenderung menentukan pilihan atas pertimbangan-pertimbangan, diskusi, dan pendapat dari keluarga, lingkungan organisasi/komunitas, lingkungan pertemanan, maupun lingkungan pekerjaan. Selain itu, ada pula pemilih yang melihat agama dan jenis kelamin dari pasangan calon sebagai pertimbangan dalam menentukan pilihan.

Kedua, pendekatan psikologis. Ada pemilih yang menentukan pilihannya berdasarkan identifikasinya pada sosok dan partai pengusung. Pemilih yang loyal atau berafiliasi dengan partai tertentu, akan cenderung mendukung pasangan calon yang diusung oleh partai tersebut. Dari segi ketokohan, pemilih yang sudah lama merasakan kontribusi dan kharisma pasangan calon akan sepenuhnya mendukung pasangan calon. Kharisma pasangan calon terbentuk dari interaksi dalam waktu yang cukup lama antara pemilih dan pasangan calon, sehingga timbul ikatan antara pemilih dengan pasangan calon. Hal tersebut juga berlaku antara pemilih dengan partai politik.

Ketiga, pendekatan rasional. Pendekatan ini sudah mulai banyak dilakukan oleh pemilih. Pemilih melihat visi misi dan program kerja yang ditawarkan oleh pasangan calon melalui kampanye langsung maupun melalui media. Pemilih juga mencari tahu tentang track record dari kelima pasangan calon. Meskipun pendekatan sosiologis masih 
mendominasi perilaku pemilih, namun pendekatan rasional juga mulai banyak digunakan oleh pemilih. Seiring meningkatnya tingkat edukasi dan kesadaran politik, maka semakin tinggi pula tingkat rasionalisasi pemilih dalam menentukan calon pemimpin.

Keempat, pemilih yang tidak menggunakan hak pilihnya selain karena masalah teknis adalah karena pemikiran skeptis bahwa pemimpin tidak akan bisa amanah atau pemimpin tidak mampu mensejahterakan rakyatnya, juga karena tidak mendapatkan jatah amplop sehingga mereka enggan untuk memberikan suaranya.

Kelima, pemilih penyandang disabilitas yang selama ini sering termarjinalkan mendapatkan kesempatan yang lebih luas dalam pilkada. Selain memberikan suara, mereka juga ikut terlibat dalam penyusunan pertanyaan untuk debat calon Bupati-Wakil Bupati Kabupaten Kudus.[]

\section{Daftar Pustaka}

As'ad, Moh. 2002. Psikologi Industri: Seri Ilmu Sumber Daya Manusia. Yogyakarta: Liberty.

Damita, Nabilah Ayu, Mohamad Yudhi Batubara, dan Nurudin Hady. 2014. "Tingkat Partisipasi Politik dalam Pemilihan Kepala Daerah Tahun 2013 di Kabupaten Lumajang." Jurnal Pendidikan Kewarganegaraan Universitas Negeri Malang 1(1).

Damsar, Sinta. 2015. Pengantar Sosiologi Politik. Jakarta: Kencana Prenada Media.
Khoirudin. 2004. Partai Politik dan Agenda Transisi Demokrasi. Yogyakarta: Pustaka Pelajar.

Koentjaraningrat. 2011. Pengantar Antropologi. Jakarta: Rineka Cipta.

Kristiadi, J. 1996. Pemilihan Umum dan Perilaku Pemilih di Indonesia. Jakarta: LP3ES.

Liando, Daud M. 2016. "Pemilu dan Partisipasi Politik Masyarakat (Studi pada Pemilihan Anggota Legislatif dan Pemilihan Presiden dan Calon Wakil Presiden di Kabupaten Minahasa Tahun 2014)." Jurnal LPPM Bidang EkoSosBudKum 3(2):14-28.

Mahendra, A. A. Oka. 2005. Pilkada di Tengah Konflik Horisontal: Nurmahmudi Ismail Unggul di KPUD, Badul Kamal Menang di Pengadilan Tinggi. Jakarta: Millenium Publisher.

Majelis Umum PBB. 1948. Deklarasi Universal Hak-hak Asasi Manusia. Diambil (https://www.komnasham.go.id/files/ 1475231326-deklarasi-universal-hakasasi--\$R48R63.pdf).

Nazir, Mohammad. 1998. Metode Penelitian. Jakarta: Ghalia Indonesia.

Nursal, Adman. 2004. Political Marketing: Strategi Memenagkan Pemilu. Jakarta: Gramedia Pustaka Utama.

Sastroatmojo, Sudijono. 1995. Perilaku Politik. Semarang: IKIP Semarang Press.

Surbakti, Ramlan. 2007. Mamahami Ilmu Politik. Jakarta: Gramedia Widiasarana Indonesia.

Surbakti, Ramlan. 1997. Partai Pemilu dan Demokrasi. Yogyakarta: Pustaka Pelajar. 
Syaifuddin, Ahmad Fedyani. 2015. Logika Antropologi: Suatu Percakapan Imajiner Mengenai Dasar Paradigma. Jakarta: Prenadamedia Group.

Usfinit, Yustinus, Agung Suprojo, dan Dody Setyawan. 2014. "Perspektif Partisipasi Politik Masyarakat pada Pemilihan Kepala Daerah (Pilkada) Kota Malang." JISIP: Jurnal Ilmu Sosial dan Ilmu Politik 3(1):38-45.

Wardhani, Primandha Sukma Nur. 2018. "Partisipasi Politik Pemilih Pemula dalam Pemilihan Umum." Jupiis: Jurnal Pendidikan Ilmu-ilmu Sosial 10(1):5762.

\section{Referensi dan Sumber Data Lain:}

Komisi Pemilihan Umum Daerah (KPUD) Kabupaten Kudus.

Wawancara dengan Atika Rizki, Pemilih Pemula, Kecamatan Kudus.

Wawancara dengan Dadi, Pegawai Pemerintah, Kecamatan Dawe.

Wawancara dengan Dariyah, Pegawai Pemerintah, Kecamatan Jekulo.

Wawancara dengan Dewi, Akademisi Kecamatan Jekulo.

Wawancara dengan Dewi, Pendidik, Kecamatan Dawe.

Wawancara dengan Dian, Pegawai Swasta, Kecamatan Bae.

Wawancara dengan Erlin, Pemilih Pemula, Kecamatan Kaliwungu.

Wawancara dengan Etika Puspa Sari, Pendidik, Kecamatan Kudus.

Wawancara dengan Fanni Fatoni, Akademisi, Kecamatan Kudus.
Wawancara dengan Fatah, Pegawai Swasta, Kecamatan Kudus.

Wawancara dengan Harti, Pemilih Pedesaan, Kecamatan Bae.

Wawancara denganIna Filasari, Pendidik, Kecamatan Jati.

Wawancara denganIsnawati, Pegawai Pemerintah, Kecamatan Dawe.

Wawancara dengan Lana Alfiyana, Pengusaha Café, Kecamatan Kudus.

Wawancara dengan Mbah Darjo, Pensiunan dan Lanjut Usia, Kecamatan Undaan.

Wawancara dengan Mega, Pemilih Pedesaan, Kecamatan Jati.

Wawancara dengan Mus, Lanjut Usia, Kecamatan Kudus.

Wawancara dengan Nada, Pemilih Pemula, Kecamatan Kudus.

Wawancara dengan Nurus dan Amrul penyandang disabilitas dari Kecamatan Bae.

Wawancara dengan Pi'an, Pemilih Pedesaan, Kecamatan Kaliwungu.

Wawancara dengan Puji Kurniasih, Pemilih Pemula, Kecamatan Jati.

Wawancara dengan Reza, Buruh, Kecamatan Bae.

Wawancara denganRia, Pegawai Swasta, Kecamatan Gebog.

Wawancara dengan Rismawan, Disabilitas, Kecamatan Mejobo.

Wawancara dengan Rodiyah, Pemilih Lansia, Kecamatan Bae.

Wawancara dengan Rudi, Buruh, Kecamatan Bae. 
Mas'udi, Umi Qodarsasi, Nevy Rusmarina Dewi

Wawancara dengan Sari, Buruh, Kecamaan Jekulo.

Wawancara dengan Saridi, Pegawai Pemerintah, Kecamatan Kudus.
Wawancara dengan Siti, Pemilih Pemula, Kecamatan Kudus.

Wawancara dengan Sri Wahyuni, Buruh, Kecamatan Jati. 